\title{
Using New Generation Additives in Highly Productive Cattle Feeding
}

\author{
Ivanova I.Ye. \\ FSBEI of Higher Education "Northern Trans-Ural State \\ Agricultural University" \\ Tyumen, RF \\ e-mail danik1969@mail.ru
}

\author{
Ivanova A.S \\ FSBEI of Higher Education "Northern Trans-Ural State \\ Agricultural University" \\ Tyumen, RF \\ e-mail aniuta.anna1987@yandex.ru
}

\begin{abstract}
High-producing cows react to insufficient and low quality feeding which results in productivity loss. That is why, ration should be balanced with all nutritious and biologically active substances with the use of highly effective special additives. Microelements and vitamins deficit can be reduced by introducing them with the food or as balls (bolli) into the rumen. Influence of new generation additives in the form of Bioplex and long acting balls on milk producing activity and physiological state of highly productive cows have been studied. Nourishing organism with vitamins and minerals during a dry period and yielding increases milk productivity. Application of balls in the first experiment increased productivity by $7,2 \%$, and in the second experiment introduction of Bioplex in the ration by $13,7 \%$. Introducing additives normalizes metabolic processes.
\end{abstract}

Key words-milk productivity, blood, balls, Bioplex, ration

\section{INTRODUCTION}

Northern Trans-Ural region is a biogeochemical province with deficit in some microelements.

Mineral composition study showed that fodder on farms in Tyumen region are poor in iron and cuprum in haylage, silage is poor in iron, herbage is poor in cobalt and cuprum comparing with the similar fooder in other regions. Iron content in grain differs significantly. Barley and wheat contain 129-168.6 $\mathrm{mg} / \mathrm{kg}$, and oat grain and grain mixture have $478-630 \mathrm{mg} / \mathrm{kg}$ of fooder, or 3.8 times higher. This difference is found in haylage from different crops. Comfrey-oat haylage contains just 102 $\mathrm{mg} / \mathrm{kg}$ of iron, and perennial grass haylage about $602 \mathrm{mg} / \mathrm{kg}$. Cuprum content in the studied samples is low, except for silage and hay. In hay this element content varies from 4.5 to 7.37 $\mathrm{mg} / \mathrm{kg}$, in hay from 4.5 to $5.8 \mathrm{mg} / \mathrm{kg}$. Zink content in the studied fooder is also in wide ranges: from 14.90 to $40.50 \mathrm{mg} / \mathrm{kg}$ in hay, from 13.80 to 20.10 in silage, from 10.50 to 22.01 in haylage and from 17.00 to $25.00 \mathrm{mg} / \mathrm{kg}$ in concentrates. In fooder of southern part of Tyumen region there is low cobalt content. Grain fooder contains $0.18-0.23 \mathrm{mg} / \mathrm{kg}$, except for grain mixture, which contains $0.63 \mathrm{mg} / \mathrm{kg}$ of fooder. These variations in cobalt content are observed in silage: corn silage contains 3.7 times less cobalt then sunflower and corn-sunflower silage [1].

Thus, mineral elements content in Northern Trans Ural fooder differs from their average content in Siberian fooder. In this connection when combining fooder rations for agricultural animals and calculating the amount of mineral additives it is better to use specific data of fooder mineral composition [2].

Due to this fact it is impossible to make an adequate diet from existing range of feeding materials, especially for the period of long pregnancy and after parturition, when hypovitaminosis and hypomicroelementosis are formed $[3,4]$.

High producing cows are especially demanding for highly nutritious feeding, which is conditioned by intensive metabolic processes at the end of dry period and at the beginning of lactation period.

High producing cows are very sensitive to insufficient and low quality feeding, and even insignificant change in ration results in low productivity. That is why, rations should be balanced by all nutritious and biologically active substances with the use of highly effective special additives [5].

The main factor of disease prevention during dry and puerperal periods is providing cows with sufficient amount of vitamins and microelements [6].

Mineral substances are important in cattle feeding. They are material for skeleton construction, take part in digestion processes, regulate osmotic pressure and keep acid-base balance in the organism. Mineral matters in cells are in the form of solutions and mineral compounds. Also, mineral matters take active part in protein, fat, carbohydrate metabolism; hormonal functioning is also impossible without them. Mineral matters influence energetic, nitrous, carbohydrate and lipid exchange; they are structural material of organs and tissues; they are a part of organic substances, keep immune functions of organism, deactivate poisonous substances [7].

When macro- and micro - elements are added to the main ration, productivity increases by $8-10 \%$, fooder consumption decreases by $10-12 \%$ per unit [8]

Microelements and vitamins can be introduced in different ways: with water, fooder, by injections [9].

It has been proved that most of vitamins and minerals are lost without absorption and influencing metabolic processes when they are introduced by zond administration. An alternative way of introducing vitamins and minerals is by balls (bolli) $[3 ; 10]$. 
Influence of nourishing fooder on the cows' health, microelement and vitamins deficit necessitated the study of feed additives of new generation.

Bioplexes are feed additives containing organic complexes of microelements with amino acid and peptides. The advantages of Bioplex have been proved by science and practice experiments on pigs and poultry, but it is not well studied on cattle [11].

Thanks to organic form microelements of Bioplexes are easily absorbed and digested even in stress situations without antagonistic interaction with other microelements and nourishing agents. It is their unique advantage in comparison with inorganic sources of minerals in feeding and metabolism: better absorption in intenstinal; proteinate are absorbed in thin intestinal as amino acid and peptides, unlike metal ions (by diffusion); they do not compete with other minerals for digestion areas; they are more stable and protected from binding with other minerals and nourishing agents. Metabolic advantages: better retention in tissues; organic forms of the microelements create reserves in tissues, sufficient for protection from diseases and keeping high reproductive parameters of animals; proteinate are transferred in an organism unlike ions; they reach organs and tissues easily; they are better absorbed, no overdoses are necessary; environmental contamination decreases $[12,11]$.

Studies on zinc and cuprum provision of ruminants with the account of productivity and type peculiarities, as well as regional conditions of crop production, have scientific and practical value and determine topicality of the conducted studies.

The purpose of the studies was to determine the influence of long acting feed additive MegaBrick Prepavel and introducing zinc and cuprum elements in Bioplexes into cows ration during milk yielding.

The object of the study was:

- to determine the influence of MegaBrick Prepavel balls on milk productivity;

- to determine zinc and cuprum influence in the form of Bioplexes on milk productivity;

- to study cows' morphologic and blood chemical value when using Bioplexes and balls.

The experiment has been conducted on the JSC "Industrial Farm of Northern Trans-Ural State Agricultural University" during winter stall feeding period, on black-and -white cows during dry and milk yielding periods.

\section{METHODS AND MATERIALS}

Methods of studying Bioplexes balls influence on productivity and physical condition of cows were identical. For the experiments, groups of animals were formed by principles: analogue couples with the account of breed, age, live weight, productivity and physical state 10 heads in each group. The control group received ordinary household fooder and cows in experimental group received mineral additives - two Megabrick Prepavel balls with the help of a sounder for dry cows in the first experiment. This provides maximum absorption of the components. The composition of balls was the following: calcium $10000 \mathrm{mg}$; phosphorus $1400 \mathrm{mg}$; zinc 16 $800 \mathrm{mg}$; cuprum $5200 \mathrm{mg}$; cobalt $80 \mathrm{mg}$; magnesium 18000 mg; selenium $170 \mathrm{mg}$; iodine $160 \mathrm{mg}$; E vitamin $13500 \mathrm{mg}$; A vitamine $3000000 \mathrm{ME}$. Balls were introduced two months before parturition.

Megabrick Prepavel efficiency is based on complex long lasting action of the components. Vitamins and minerals complex of Megabrick Prepavel makes parturition easier, improves mamas resistance and regeneration, improves colostral milk quality and reinforces calves immunity.

In the second experiment the cows in the experimental group received additionally mineral additives to the main fooder Bioplex Zinc 3,6 g and Bioplex Cuprum 0,69 g per capita a day during milk yielding period.

Housing and feeding conditions of all experimental animals were the same. To control nourishment and health state of the cows morphological and blood chemistry rates were studied. The blood was taken from the dock of three animals in each group at the beginning and the end of the experiment. In blood and its serum we determined: total protein, glucose, alkali reserve, calcium, phosphorus and carotene. The analyses were done at the clinical laboratory of FSBEI of HPE "Northern Trans-Ural SAU".

Milk productivity was estimated by test milking once a month. Mass fraction of protein and fat was determined in milk chemical composition. Milk analysis was conducted with "Lactan 1-4".

Milk productivity is the main criteria for estimating balance and usefulness of feeding as well as productive action of feed additives in dairy cattle breeding [13].

\section{RESULTS OF DISCUSSIONS}

In order to make milk more useful and nourishing specialists recommend to introduce special feed additives with high macro elements and microelements content (as a rule, deficit in our conditions $\mathrm{Zn}, \mathrm{Cu}, \mathrm{Co}, \mathrm{I}, \mathrm{Se}$ ) and vitamins (A, D, E) into cows ration especially during dry period and milk yielding period.

The data evidenced that experimental cows which received mineral additives showed their genetic potential fully and used nourishing substances for milk yielding more effectively. These data are given in tables 1 and 2 .

TABLE 1. MILK PRODUCTIVITY OF COWS DURING BALLS (BOLLI) INTRODUCTION $(\bar{X} \pm \mathrm{S} \bar{x})$

\begin{tabular}{|l|l|l|}
\hline \multicolumn{1}{|c|}{ Index } & \multicolumn{1}{c|}{ Control group } & \multicolumn{1}{c|}{ Experimental group } \\
\hline Milking yield, $\mathrm{kg}$ & $6009.52 \pm 64.63$ & $6476.19 \pm 66.12$ \\
\hline Fat mass share, $\%$ & $3.74 \pm 0.15$ & $3.78 \pm 0.09$ \\
\hline Fat mass, $\mathrm{kg}$ & $224.75 \pm 5.8$ & $244.79 \pm 3.69$ \\
\hline Protein mass share, $\%$ & $3.09 \pm 0.04$ & $3.19 \pm 0.03$ \\
\hline Protein mass, $\mathrm{kg}$ & $185.69 \pm 2.07$ & $206.59 \pm 2.56$ \\
\hline
\end{tabular}


By the end of lactation the experimental cows gave on average $6476.19 \mathrm{~kg}$ of milk with fat share $3.78 \%$ and protein $3.19 \%$. Organism enriching with minerals and vitamins during dry period allowed increasing milk productivity by $7.7 \%$ and enhances milk fat quality by $0.04 \%$ and milk protein by $0.1 \%$.

TABLE 2. MILK PRODUCTIVITY DURING THE PERIOD OF BIOPLEXES APPLICATION (THE FIRST 90 LACTATION DAYS $)(\bar{X} \pm \mathrm{S} \bar{x})$

\begin{tabular}{|l|c|c|}
\hline \multicolumn{1}{|c|}{ Index } & \multicolumn{2}{c|}{ Groups } \\
\cline { 2 - 3 } & control & experimental \\
\hline $\begin{array}{l}\text { Milk yielding during 90 } \\
\text { lactation days, kg: }\end{array}$ & & \\
\hline natural fatness & $2120.3 \pm 90.46$ & $2410.0 \pm 131.62$ \\
\hline $4 \%$ fatness & $2146.5 \pm 84.32$ & $2560.6 \pm 104.31$ \\
\hline Average daily milk yield, kg & & \\
\hline natural fatness & $23.56 \pm 0.90$ & $26.78 \pm 1.42$ \\
\hline $4 \%$ fatness & $23.85 \pm 0.70$ & $28.45 \pm 1.02^{* *}$ \\
\hline fat mass share, \% & $4.05 \pm 0.11$ & $4.25 \pm 0.11$ \\
\hline Milk fat, kg & $85.87 \pm 2.39$ & $102.43 \pm 3.45^{* *}$ \\
\hline Protein mass share, \% & $3.11 \pm 0.05$ & $3.17 \pm 0.03$ \\
\hline Milk protein, $\mathrm{kg}$ & $65.94 \pm 5.51$ & $76.4 \pm 5.78^{* *}$ \\
\hline
\end{tabular}

Here and further $* \mathrm{P}<0.05 ; * * \mathrm{P}<0.01 ; * * * \mathrm{P}<0.001$

After Bioplexes application experimental cows showed better milking productivity than those of the control group. For the first 90 lactation days they gave $13.7 \%$ more milk of natural fatness. Fat extraction was evidenced $16.56 \mathrm{~kg}$ more or by $19.28 \%(\mathrm{P}<0.01)$, and milk protein by $10.46 \mathrm{~kg}$ more, or by $15.86 \%(\mathrm{P}<0.01)$.

All processes in organism influence morphological composition of blood, its physic-chemical properties which evidence metabolism intensivity responsible for animals' productivity. Hematological status allows observing different changes in animals organism which depend on feeding and housing [14].

It also allows determining nourishing and housing condition for animals. Taking into account the important role of blood, a biochemical analysis of blood serum was conducted as well as blood biochemical composition before and at the end of the experiment.

There were no significant differences in blood biochemical composition between cows of both groups. In this study mineral metabolism of cows was estimated accourding to the following criteria: alkaline phosphatase, reserve acidity, calcium, phosphorus, iron, magnesium, potassium, sodium. There was lack in some minerals or they were present within the lowest normal limit, these are calcium, magnesium, iron.

Alkali reserve of blood serum is lower normal limits, but this condition may be caused by long stable housing during winter, so this deviation from norm is possible. At the end of the experimental period there was the second biochemical analysis of blood serum composition. The results are given in Table 3.

Alkali reserve index shows mineral nutrition adequacy. When mineral nutrition is insufficient organic acids accumulate in the organism and alkali reserve decreases, which can be seen in the control group. In the experimental group alkali reserve is within normal limits and increased in comparison with the beginning of the experiment by $31.46 \%$.
Calcium level is very high during the dry period, and at the end of pregnancy it decreases slowly and it is minimal after parturition. There was no such regularity may be due to mineral balls (bolli) introduction.

TABLE 3. BIOCHEMICAL BLOOD PICTURE DURING BALLS (BOLLI) APPLICATION $(\bar{X} \pm \mathrm{S} \bar{x})$

\begin{tabular}{|c|c|c|c|c|c|}
\hline \multirow[b]{2}{*}{ index } & \multicolumn{2}{|c|}{ control group } & \multicolumn{2}{|c|}{$\begin{array}{l}\text { experimental } \\
\text { group }\end{array}$} & \multirow[t]{2}{*}{$\begin{array}{c}\text { norma } \\
1 \\
\text { limits }\end{array}$} \\
\hline & $\mathrm{X} \pm \mathrm{S}$ & $\begin{array}{l}\mathrm{Cv} \\
\%\end{array}$ & $\mathrm{X} \pm \mathrm{s}$ & $\begin{array}{c}\mathrm{Cv} \\
\%\end{array}$ & \\
\hline Total protein, g/l & $68.83 \pm 4.94$ & 8.57 & $80.9 \pm 7.4$ & $\begin{array}{c}10.4 \\
6\end{array}$ & $72-86$ \\
\hline Globulin.g/l & $37.17 \pm 1.98$ & 5.23 & $42.9 \pm 1.65$ & 4.95 & $7.2-8.6$ \\
\hline Albumin,g/l & $31.66 \pm 4.25$ & 7.37 & $38.00 \pm 4.0$ & 5.65 & \\
\hline Calcium, mmol/1 & $2.68 \pm 0.22$ & 0.39 & $2.78 \pm 0.13$ & 0.18 & $2.5-3.5$ \\
\hline $\begin{array}{l}\text { Phosphorus, } \\
\mathrm{mmol} / \mathrm{l}\end{array}$ & $1.99 \pm 0.32$ & 0.55 & $1.75 \pm 0.09$ & 0.13 & $\begin{array}{l}1.45- \\
1.94\end{array}$ \\
\hline Iron, mmol/1 & $25.88 \pm 0.55$ & 0.86 & $28.84 \pm 2.13$ & 3.01 & $16-20$ \\
\hline $\begin{array}{l}\text { Magnesium, } \\
\mathrm{mmol} / \mathrm{l}\end{array}$ & $0.78 \pm 0.05$ & 0.08 & $0.80 \pm 0.05$ & 0.07 & $\begin{array}{l}0.82- \\
1.23\end{array}$ \\
\hline $\begin{array}{l}\text { Potassium, } \\
\mathrm{mmol} / \mathrm{l}\end{array}$ & $4.68 \pm 0.55$ & 0.95 & $4.45 \pm 0.02$ & 0.28 & $\begin{array}{c}4.1-4- \\
86\end{array}$ \\
\hline Sodium, mmol/1 & $125.7 \pm 2.21$ & 3.84 & $\begin{array}{c}131.75 \pm 1.1 \\
5\end{array}$ & 1.62 & $\begin{array}{c}139- \\
148\end{array}$ \\
\hline $\begin{array}{l}\text { Trygleciride, } \\
\mathrm{mmol} / \mathrm{l}\end{array}$ & $0.25 \pm 0.01$ & 0.01 & $0.24 \pm 0.01$ & 0.02 & $\begin{array}{l}0.03- \\
0.55\end{array}$ \\
\hline $\begin{array}{l}\text { Alkaline } \\
\text { phosphatase,Uni } \\
\text { ts }\end{array}$ & $\begin{array}{c}125.3 \pm 16.6 \\
6\end{array}$ & $\begin{array}{c}28.8 \\
6\end{array}$ & $\begin{array}{c}134.00 \pm 4.0 \\
0\end{array}$ & 5.65 & $\begin{array}{l}110- \\
390\end{array}$ \\
\hline $\begin{array}{l}\text { Reserve acidity, } \\
\text { vol } / \% \mathrm{CO} 2\end{array}$ & $45.69 \pm 1.65$ & & $63.88 \pm 1.91$ & & $\begin{array}{l}46.0- \\
66.0\end{array}$ \\
\hline
\end{tabular}

As data from table 3shows there were changes in animals' organisms.

Average alkaline phosphatase activity in experimental group was 134.2 Units, that is within normal limits, but rather high. In general, it proves high metabolic processes.

Magnesium ion content is within normal limits in the blood.

Iron micro element which was studied in blood serum somewhat exceeds the norm, but at the same time total protein level increases $(80.9 \mathrm{~g} / \mathrm{l}$ in the experimental group).

The other indexes are within normal limit.

When the long acting additive is introduced into the dry cows' fooder, there is normalization of other indexes of blood content (total protein, albumin, and globulin, alkali reserve, calcium and magnesium).

Table 4 shows serum biochemical study indexes of cows who received mineral additives as balls (bolli).

During milk yielding period the cows from experimental group had calcium $9.44 \%$ higher than those of the control group. The situation is different about inorganic phosphorus 
level. Cows in the experimental group had phosphorus 1.44 $\mathrm{mmol} / \mathrm{l}$. There was no significant difference.

TABLE 4. BIOCHEMICAL BLOOD CHARACTERISTICS DURING BIOPLEX APPLICATION $(\bar{X} \pm \mathrm{S} \bar{x})$

\begin{tabular}{|l|c|c|}
\hline \multirow{2}{*}{ Index } & \multicolumn{2}{|c|}{ Group } \\
\cline { 2 - 3 } & control & experimental \\
\hline Calcium, mmol /1 & $2.33 \pm 0.06$ & $2.55 \pm 0.22$ \\
\hline $\begin{array}{l}\text { Inorganic phosphorus, } \\
\text { mmol/1 }\end{array}$ & $1.42 \pm 0.20$ & $1.44 \pm 0.11$ \\
\hline Alkali reserve, mg \% & $559.04 \pm 8.79$ & $588.01 \pm 7.75^{*}$ \\
\hline Total nitrogen mg \% & $1105.96 \pm 81.95$ & $1071.31 \pm 12.35$ \\
\hline Residual nitrogen, $\mathrm{mg} \%$ & $31.58 \pm 5.74$ & $31.58 \pm 10.34$ \\
\hline
\end{tabular}

Blood active response is conditioned by hydrogen and hydroxyl ions. Plasma bicarbonates stock able to neutralize metabolism acids are called alkali blood reserve. Alkali reserve level is $5.18 \%(\mathrm{P}<0.05)$ higher in experimental group in comparison with control group.

Serum proteins are plasma proteins which remain after extracting blood corpuscle and fibrinogen. Total protein content in animals with high productivity can decrease due to intensive metabolism caused milk synthesis $[15,14]$.

There is a close connection between productivity level, milk quality, and protein composition of milk. As total protein content is lower during productive period in animals which are more productive [16].

TABLE 5. TOTAL PROTEIN AND ITS FRACTION CONTENT IN COWS BLOOD WHEN USING BIOPLEXES $(\bar{X} \pm \mathrm{S} \bar{x})$

\begin{tabular}{|l|c|c|}
\hline \multirow{2}{*}{\multicolumn{1}{|c|}{ Index }} & \multicolumn{2}{c|}{ Group } \\
\cline { 2 - 3 } & control & experimental \\
\hline Total protein, g/1 & $66.67 \pm 5.14$ & $65.42 \pm 0.79$ \\
\hline Albumin, \% & $34.67 \pm 0.34$ & $39.07 \pm 1.96^{*}$ \\
\hline Globulin \% including: & $65.33 \pm 0.48$ & $60.93 \pm 0.11^{*} *$ \\
\hline$\alpha$-globulin & $15.42 \pm 0.43$ & $15.95 \pm 0.86$ \\
\hline$\beta$ - globulin & $9.37 \pm 0.45$ & $9.61 \pm .10$ \\
\hline$\gamma$-globulin & $40.54 \pm 0.49$ & $37.37 \pm 1.15$ \\
\hline Protein concentrate & $0.53 \pm 0.01$ & $0.64 \pm 0.05^{*}$ \\
\hline
\end{tabular}

Analyzing the data it should be noted that total serum protein content was within normal limits.

Total protein content in control group was $1.9 \%$ higher than in experimental group. Albumin is FPF, have low viscosity and make blood more movable that facilitates cardio functioning regarding fast blood circulation in blood vascular system. They provide transport of intermediate metabolism products after prehydrolysis, release amino acids used for specific protein synthesis. Consequently, high albuminous fraction content is directly connected with animals' productivity [18, 19]. The study proved that experimental group has higher albumin per cent in blood serum. It is significantly higher $(\mathrm{P}<0.05)$ in comparison with control group 5.0\%. Globulin is proteins with different structure and important biological functions. Globulin fraction of serum protein transports lipids, estrogens, lipid soluble vitamins, and includes alpha-, beta-, gamma- globulin. Highly productive animals had lower globulin fraction during milk yielding period due to gamma-globulin decrease. Globulin content in blood serum is significantly $(\mathrm{P}<0.01)$ lower in experimental group by $4.4 \%$ in comparison with the control group.

Beta-globulin transport lipids in blood. Level of betaglobulin fraction in the experimental group is higher than in control group by $2.56 \%$. During intensive lactation highly productive cows have lower gamma-globulin content. According to G.S. Azaubaeva (2004) milk productivity has negative correlation with gamma-globulin content in cows' blood serum. So, the experimental group gamma-globulin content is $3.17 \%$ lower comparing with the control one $[14,19,20]$.

When albumin fraction increases a protein coefficient increases as well. Protein coefficient in experimental group is $20.75 \%$ higher than in the control group $(\mathrm{P}<0.05)$.

Thus, we can say that cows in the experimental group, which received chelate zinc and cuprum components as feed additives had greater productivity which influenced morphological and biochemical blood indexes, which changed greater than those in the control group. Changes in blood protein composition evidence more intensive metabolism and consequently better absorption of fooder protein.

During adding zinc and cuprum Bioplexes biochemical and morphological blood indexes were within normal limits, that evidences normal metabolism in cows' organisms.

\section{CONCLUSION}

Thus, feed additive Mega Brick Prepavel given to a cow as a ball into rumen, where it dissolves gradually providing maximum components absorption and mineral substances in the form of Bioplex had no negative influence on biochemical blood indexes and allowed increasing milk productivity.

\section{References}

[1] I. Ye. Ivanova, M.G. Volynkina, "Increasing milking capacity, reproductive qualities improvement and metabolism normalization in cows after introducing feed additives", North Trans Ural State Agrarian University Bulletin, 2014, №2925, pp.35-38.

[2] M. G. Babakina, "Using mineral-vitamin premix for improving adequate diet of black-white cows during milk yielding period", dissertation synopsis for candidate of agricultural science degree, Kurgan, 1998, p. 20.

[3] S. Kuznetsov, A. Kuznetsov, "Vitamins and minerals in cows' reproductive function regulation”, Dairy and beef raising, 2010, № 5, pp. 32-34.

[4] N. Mukhina, A. Smirnova, A. Smirnov, "Mineral additives regulating acid-base balance in animals ration", Feeding farm animals and food cropping, 2007, № 7, pp. 41-42.

[5] V.N. Zayats, A.V. Kvetkovskaya, M.A. Nadarinskaya, "Feeding high productive cows with propilenglicole in complex with nicotinic acid and glycerin”, Feeding farm animals and food crops production, 2009, № 1, pp. 20-23.

[6] Ju.N. Alekhin, "Significance of energetic feeding in providing reproductive function of cows", Modern issues of animals' reproductive health veterinary provision: collection of scientific works ARSRVIPPT, Voronezh, 2009, pp. 28-32.

[7] N.A. Lushnikov, "Mineral substances and natural additives in animals feeding”, Kurgan: KSAA, 2003, p. 192.

[8] A.A. Kurdoglyan "Cows' milk yielding with corn silage and concentrates enriched with feed additive”, Feeding and food cropping, 2013, № 2, pp. 22-35. 
[9] D.V. Vorobjev et al, "Physiological status and its correction in ruminant, omnivores and poultry in biochemical conditions of Downstream Volga region: monograph", Saint-Petersburg: Lan', 2011, p.180.

[10] M. Casalone, "Mineral metabolism during late pregnancy and calcium status after parturition in dairy cows", Poster at the 25th World Buiatrics Congress, 2008, № 6, pp. 338.

[11] V. Nadeev, M. Chabaev, R. Nekrasov, Yu. Klementieva, M. Klementiev, "Utilization efficiency of organic cuprum form in fattened pigs ration", Glavniy Zootekhnik, 2012, № 5, pp. 22-26.

[12] D.V. Pchelnikov, "Chelat microelements compositions for preventing and treating hypomicroelementos of animals", Current issues of veterinary medicine: Materials of Siberian International veterinary congress, Novosibirsk State Agricultural University, Novosibirsk, 2005, p. 226.

[13] M. Kirilov, V. Vinogradov, V. Zoteev, "Premixes for cows in Kamchtka", Dairy and beef cattle breeding, 2007, № 5, pp. 15 - 16 .

[14] G.S. Azaubaeva, "Blood picture of animals and poultry", Kurgan: SRPP "Trans Ural", 2004, p. 168.

[15] S.G. Kuznetsov, V.I. Kalashnik, "Efficiency of premixes in milking cows feeding”, Zootechnics, 2002, № 2, pp. 14-18.

[16] G.S. Azaubaeva, "Connection of morphobiochemical blood composition and milk productivity of cows during utilization of different metabolizable energy in rations”, Glavniy Zootekhnik, 2009, № 5, pp. 19-25.

[17] M. Yudin, T. Mukasheva, "Housing conditions influence on behaviour and milk productivity of black and white and Holstein cows", Glavniy Zootekhnik, 2011, № 3, pp. 39-46.

[18] S.D. Batanov, O.S. Starostina, "Blood composition and its connection with milk productivity”, Zootechnics, 2005, №10, pp.14-15.

[19] M.G. Volynkina, I.Ye. Ivanova, O.V. Kovaleva, "Feed additives in cattle breeding in Tyumen region”, Tyumen: SAU Publishing House, 2017, p. 152.

[20] R. Jorritsma. T. Wensing. T. A. M. Kruip, "Metabolic changes in early lactation and impaired reproductive performance in dairy cows" Vet. Res., 2003, Vol. 34, № 1, pp. $11-26$. 